\title{
The Priest of Han as a Theme in the Christian-Shamanist Interfaith Dialogue
}

\author{
Kang, Won Don*
}

\begin{abstract}
In the article I would see into the 'priest of han' as a theme which Nam-dong Suh, one of the fathers of the Minjung theology, has developed, and suggest how he has made a creative and critical encounter with the shamanistic hanpuri. First, I examine in the first step how influential the shamanism is still in Korean society. In this connection I would investigate briefly how the shamanism is incorporated in Korean Protestantism. Second, I explain han and hanpuri in the context of Korean shamanism. Third, I analyze how the Minjung theology has employed the themes of han and hanpuri. Lastly, I give some suggestions about a spiritual formation for the ministry. From the Christian encounter with the shamanism I draw a few consequences. First of all, I suggest that Christian minister should learn something from the attitude of shamans towards the weak and oppressed. They have "a special predilection for the weak and oppressed" (I. M. Lewis) and are ready to be in solidarity with others in suffering. Of course, Christian minister need not to suffer the initiation sickness like shamans, but they must be trained to attain a spiritual competency to sympathize and to be in solidarity with the little people in suffering. Second, I think that the church should be earnest to the priesthood of han. It is not just the duty of the minister. The priesthood of han should be reinterpreted from the perspective of the priesthood of all believers.
\end{abstract}

Key-words: initiation illness, han, hanpuri, shamanism, Minjung theology, priest, suffering

\section{O sacerdote de Han como um tema no diálogo inter-religioso cristão-xamãnista}

\section{Resumo}

No artigo eu procuro explorar o 'sacerdote de han' como um tema que Nam-dong Suh, um dos pais da Teologia Minjung desenvolveu, na tentativa de sugerir como ele fez um encontro criativo e crítico com o xamanismo hanpuri. Em primeiro lugar, eu examino o quão influente o xamanismo ainda está na sociedade coreana. Neste contexto, eu procuro investigar brevemente como o xamanismo é incorporado no protestantismo

\footnotetext{
Hanshin University
} 
coreano. Em segundo lugar, explico os significados de han e de hanpuri no contexto do xamanismo coreano. Em terceiro lugar, analiso como a Teologia Minjung tem empregado os temas de han e hanpuri. Por fim, dou algumas sugestões sobre uma formação espiritual para o ministro cristão. Do encontro cristão com o xamanismo, chamo atenção para algumas deduções. Em primeiro lugar, sugiro que o ministro cristão aprenda algo da atitude dos xamãs em relação aos fracos e oprimidos. Eles têm "uma especial predileção pelos fracos e oprimidos" (I.M. Lewis) e estão prontos para serem solidários com os outros em sofrimento. É claro que o ministro cristão não precisa passar pelos sofrimentos decorrentes da doença que ocorrem na iniciação dos xamãs, mas eles devem ser treinados para obter uma competência espiritual para simpatizar e estar em solidariedade com os que sofrem. Em segundo lugar, penso que a igreja deve ser sincera ao sacerdócio de han, que não é apenas o dever do ministro cristão, mas deve ser reinterpretado a partir da perspectiva do sacerdócio de todos os crentes.

Palavras-chave: doença de iniciação; han; hanpuri; xamanismo; Teologia de minjung; sacerdote; sofrimento.

\section{El sacerdote de Han como tema en el diálogo interreligioso cristiano-chamanista}

\section{Resumen}

En el artículo procuro explorar el "sacerdote de han" como un tema que Nam-dong Suh, uno de los padres de la teología Minjung, desarrolló, en la tentativa de sugerir cómo él hizo un encuentro creativo y crítico con el hanpuri chamánico. Primero, examino cuán influyente todavía es el chamanismo en la sociedad coreana. En este sentido, expongo brevemente cómo se incorpora el chamanismo en el protestantismo coreano. En segundo lugar, explico han y hanpuri en el contexto del chamanismo coreano. Tercero, analizo cómo la teología minjung ha empleado los temas de han y hanpuri. Por último, doy algunas sugerencias sobre una formación espiritual para el ministerio. Del encuentro cristiano con el chamanismo saco algunas consecuencias. En primer lugar, sugiero que el ministro cristiano debería aprender algo de la actitud de los chamanes hacia los débiles y oprimidos. Tienen "una predilección especial por los débiles y oprimidos" (I. M. Lewis) y están listos para ser solidarios con otros en el sufrimiento. Por supuesto, el ministro cristiano no necesita sufrir la enfermedad de iniciación como los chamanes, pero debe ser entrenado para alcanzar una competencia espiritual para simpatizar y estar en solidaridad con las pequeñas personas en sufrimiento. Segundo, creo que la iglesia debería ser sincera con el sacerdocio de han. No es solo el deber del ministro. El sacerdocio de han debe ser reinterpretado desde la perspectiva del sacerdocio de todos los creyentes.

Palabras clave: enfermedad de iniciación; han; hanpuri; chamanismo; Teología minjung; sacerdote; sufrimiento. 


\section{Preface}

In the period in which Korean minjung ${ }^{1}$ has struggled against the military dictatorship Nam Dong Suh, one of the founders of Korean minjung theology, has suggested that the church should be engaged in their liberation movement and practice the priesthood of $h a n^{2}$ to relieve the minjung from their han. He has settled han as a central theme of theological reflection so that he has succeeded in shaping the very authentic form of Korean theology. But for many people who are foreign to Korean culture in which han is an underlying emotion it is somewhat difficult to understand his theology of han. Some have blamed it as uncommunicative.

Han and hanpuri, release from han, are favorite themes in various genre of the modern Korean literature and culture like poem, novel, drama, film, opera etc. At the sight of the positive response of the public to them han and hanpuri remain still as a cultural code with which Koreans are very familiar. In pansori, traditional dramatic songs, and in mask dances han and hanpuri have bound actors, audience and spectators together. Pansori and narratives in mask dances were differentiated from narratives of village festivals, the original form of which was shaman's epic. In shaman's epic that is recited in shaman rituals man can find typical expressions of han and hampuri. In the tradition one of the basic tasks of shamans was to liberate people, whether alive or dead, from their own han and it is still now the case. Therefore, without a deep understanding of Korean shamanism it would be only difficult to approach to ban which is prevalent in the emotion and mentality of the Koreans.

If the thesis of Nam Dong Suh were valid that the church ought to practice the priesthood of han, the protestant ecclesiology and ministry should be deepened and widened. A study on shaman's hampuri could be helpful in articulating new concepts on church and ministry.

In the article I would examine in the first step how influential the shamanism is still in Korean society. In this connection I would investigate briefly how the shamanism is incorporated in Korean Protestantism. Second, I would explain han and hanpuri in the context of Korean shamanism. Third,

\footnotetext{
Minjung is a Korean word for the people, who are suppressed, exploited and marginalized in the society. They seem to be silent and powerless, but under certain circumstances they express obviously their strong will to change the status quo from the bottom.

2 Cf., Nam Dong Suh, "Towards a Theology of Han," Minjung Theology: People as The Subject of History, ed. by Yong Bock Kim (Singapore: A CTC-CCA Publication, 1981), 54: Han is a "feeeling of defeat, resignation and nothingness" on the one hand. On the other, it is "a feeling with a tenacity of will for life which comes to weaker beings."
} 
I would see into how the Minjung theology has employed the themes of han and hanpuri. Lastly, I would give some suggestions about a spiritual formation for the ministry.

\section{Influential Power of the Shamanism in Korea}

The current state of the shamanism in Korea cannot be grasped in the official statistics on the side of the government. In the statistics of the Ministry of Culture, Sports and Tourism on religions there is a certain category of investigation to which the Buddhism, the Protestantism, the Catholic Church, the Confucianism, the One Buddhism, the Way to the Heaven, extra, the non-religious and no answer belong. There is no place for the Shamanism in it. ${ }^{3}$ It is very probable that the shamanistic devotees were categorized into "extra", "no answer" or "non-religious." In the religious statistics in 1994 the Buddhists amounted to $21.6 \%$ of the population, the Protestants $32.9 \%$, the Catholics $11.8 \%$, the Confucians $1.6 \%$, the One Buddhists $0.5 \%$, the Devotees to the Way to the Heaven $0.1 \%$, extra $0.9 \%$, non-religious $30.2 \%$ and no answer $0.5 \%$. In the Statistics of the Ministry of Culture, Sports and Tourism on the religious state based on the data which each religious body has issued the Daejongkyo, Worship of the nation progenitor Dangun, was added, but the shamanism left no trace there. ${ }^{4}$

Even if the state of the shamanism in Korea cannot be apprehended in the governmental statistics, the influential power of the shamanism can be estimated from a wide-spread phrase that people are Christians in the brain, Buddhists in the bosom and shamanists in the internal organs. This phrase indicates that the shamanism underlies deeply in the religiosity of the Koreans. It could be said that the shamanism forms the archetype of Korean religiosity. It has been emphasized that the shamanistic rituals has maintained their basic procedure without essential change from the antique till nowadays. ${ }^{5}$ It means that the shamanistic worldview and religiosity structure has been anchored deeply in the religious life of the Koreans and successfully transmitted from generation to generation.

\footnotetext{
3 That there is no place for the shamanism in the governmental statistics is one of the important evidences that the shamanism has been systematically excluded from the official sphere. I return to such a systematic exclusion later.

4 The religious statistics in 2002 is regarded as incredible because the total amount of believers is twice the amount of the total population.

5 In-hoe Kim, "Korean Shamanism: A Bibliographical Introduction," Shamanism: The Spirit World of Korea, ed by Chai-shin Yu and R. Guisso (Berkeley, Califonia: Asian Humanities Press, 1988), 12.
} 
Although the shamanism is not treated as official religion in the modern Korea, it exercised strong influences on the state and the community in some historical periods. Above all, shamans played a role as ruler in the ancient society. In the Gojoseon, allegedly the first monarchy in the Korean Peninsula and the Manchuria (B.C. 2333[?] B.C. 108), rulers were named Dangun; the meaning of it is shaman. ${ }^{6}$ In this point Dangun can be considered as priest-king. Gojoseon was a theocratic society in which the ruler didn't dominate the priesthood, but on the contrary the priesthood was superior to the kingship.

In the Record of Eastern Tribes in the Chronicle of Wei Kingdom in the History of Three Kingdoms by Chen Sou (A.D. $233 \sim 297$ ) there is a note worthy record as follows: "Every Year after the harvest eastern tribes eat, drink and dance together all the night; in the dawn they go to the prison, open the prison gate and liberate prisoners." 'Eastern tribes' in the quotation indicate forefathers of the Koreans in the northern area of the Korean Peninsula. 'Dance' means certainly shaman's dance, around which people danced together in orgy. It is no doubt that such a shamanistic ritual created the primitive orgy in which the exhausted energy of life could be regenerated for the next year agriculture and harvest and community members were united in strong solidarity. ${ }^{7}$ The recreation of life energy through the shamanistic ritual had a political aspect also. From the description above it can be assumed that people full of life energy broke prison and let prisoners free in order to integrate them in the communal life. Religion and politics were not separated from each other, but they were interwoven together. ${ }^{8}$ Shaman played a role of mediator and promoter for communication in the nature, among the people, and even in politics, in a word, in all the dimensions of life. ${ }^{9}$

In the period of Three Kingdoms (A.D. 4 7C) the relation between

6 Jae-hae Lim, "The political Function of Gut Culture and the Political Status of Shaman," Comparative Folklore 26 (2004/2), 240.(Korean edition) Gut means shaman's ritual.

7 Tae-gon Kim, A Study of Korean Shamanism (Seoul: Jipmoondang, 1981), $161 \mathrm{ff}$.(Korean edition)

8 Nam-hee Cha, "Political Change and Shamanism in the ancient Korean society," Korean Politics 39/2 (2005/6), 311.(Korean edition)

9 The Chinese script for shaman is $m u$ (巫). It symbolizes that shaman mediates through ecstatic dance a communication between heaven and earth. If the heaven and the earth communicate and cooperate in harmony, all the things live in fertility and prosperity. Such a communication is created also among the people through shaman's ritual which breaks down blocked barriers. 
priesthood and kingship was reversed. Shamans functioned as adviser for rulers in the state affairs as follows: maintenance of kingship, personnel matters, settlement of the public sentiment, decision of war, prosperity in agriculture and harvest, fighting off epidemic disease, flood, draught, etc. Some shamans were killed by kings because they were forthright to their rulers. (LIM, 2010, p. 254) In the period of the Unified Silla (A.D. 676-935) and in the following period of the Goryeo dynasty (A.D. 918-1392) shamans practiced the state rituals. Especially in the Goryeo dynasty shamans led the Palkwanhoe, the highest state ritual, in which the harmony among all things on the earth and under the heaven, the prosperity of the state and the welfare of the people were prayed.

But the shamanism was systematically expelled from the official sphere after the Chosun dynasty (A.D. 1392-1910) had been founded and employed the Confucianism as ruling ideology. The Confucianism dominated in the whole official sphere. The legal codices were designed according to the confucianistic principles; the highest-level state examination to recruit ranking officials were based on the knowledge of confucianistic canons; the status system, the domination structure in the village, the patriarchal family structure were reinforced under the influence of the Confucianism. The state rituals which had been practiced traditionally by shamans were abolished and the confucianistic-patterned state rituals were introduced. The ruling elite adopted the confucianistic ancestor rite. (LIM, 2010, p. 260) The shamanism withdrew in the unofficial sphere and survived barely as sub-culture. The shamanism maintained its influence among the underprivileged and especially among women who were excluded from the confucianistic family rituals. Shamans lost their dignity and formed the caste of the lowest ranking with slaves, tanner, butcher, pallbearer, monks and prostitutes.

The elite who had a strong will to modernize the state and the society from the period of the falling Chosun dynasty regarded the shamanism as the core of pre-modernity and asserted firmly on eradicating it. ${ }^{10}$ In the Japanese colonial period (A.D. 1910-1945) the shamanism was all the more severely suppressed by the authority which would eliminate the national identity of the Koreans, because it was considered as the very indigenous religion in Korea.

10 Yong-bum Lee, "A Study on the Negative View on the Shamanism in the Korean modern Society," Studies on Korean Shamanism 9 (2005/2), 163: "What is interesting here is that there is no reference to the positive aspect of the folklore religiosity in the newspapers published at the end of the Chosun dynasty and in the colonial period."(Korean edition) 
The colonial officials and the Japanese folklorists considered the shamanism as barbarian customs and, what was worse, as superstition. Such a viewpoint on the shamanism appeared also among the American missionaries who came to Korea for the purpose of preaching the Gospel. They regarded shaman's rituals and ancestor rites as superstition and asked the Koreans to convert from them to the Gospel. The negative perspective on the shamanism as superstition or pre-modern heritage prevails still among the Korean elite.

Even though the shamanism has been depreciated for a long time, it has exercised strong influences on the life of the minjung and especially on the sub-culture of women. In the tradition it has played a role to improve the well-being of the local community. Shamans have practiced the maeulgut (shaman's village ritual) periodically in order to pray for the prosperity and peace in the community and to expel misfortunes from the village. The main figure in the maeulgut was usually the shaman who was regarded as spiritual power, and who had her shrine in the village. The maeulgut has been practiced everywhere in the country, especially in the rural area and in the fishing villages. In these areas moreover $80 \%$ of the population lived even at the beginning of 1960 s when the modernization process had not been yet driven. Therefore it is no exaggeration to say that the shamanism has shaped the core of the life culture in Korea. As for shaman's rituals for individual person or family it was customary that a shaman was invited to play a certain gut to let the dead go to the good place or to release the dead in distress from his or her han; shaman's rituals were practiced in order to wipe out diseases, to expel misfortunes from the family and to bring fortunes into the family. But the shamanism has been sometimes deteriorated to the magical tool for imprecation or degraded to the machine for infantile wish-fulfillment which is closely bound with greed and avarice.

The shamanism is still powerful and influential in the modern Korea in which a sort of modernization and individualization euphoria is dominant. As is evident in the governmental statistics, the shamanism is still expelled from the official sphere. But shaman's rituals have been flexibly adapted to the changed life circumstances in the modern Korea.

All the foreign religions have gained unique colors through the prism of Korean shamanism which has formed a deep layer of Korean religiosity. Korean Buddhism has amalgamated with the shamanism, so that it has taken some elements foreign to the original Buddhism. For example, there are Samsingak and Myongbujeon in the Temple. Samsingak is originally shaman's 
shrine for Samsinhalmi, the divinity of fertility and pregnancy. Myongbujeon is the sanctuary for the ritual to lead the spirit of the dead to the Land of Happiness. Such a ritual is specific to Korean shamanism. The confucianistic ancestor rite has been activated in the background of shamanistic rituals for the dead and ancestors. In the shamanism it is believed that the spirits of the dead or ancestors haunt and bring diseases and misfortunes if they are not properly treated and appeased. According to Dong-sik Ryu, a famous indigenization theologian, who tried earnestly to make an interfaith dialogue with the shamanism, the Koreans could easily accept the Christian god in the first phase of evangelization, because they had the shamanistic concept of the supreme god in the sky. Hananim as the name of Christian God in Korean resembles Haneunim as the celestial supreme god in Korea. (RYU, 1965, p. 37)

The influence of the shamanism upon the Protestant churches in Korea is very apparent. It has left unique traits in the belief and ritual practice of Korean Protestants. Bock-kyu Lee has investigated these traits and summarized them in the following ten theses:

1. The prayer-at-dawn is closely related to the worship of 'Chowang,' one of the House Spirits.

2. The three-time calling of 'Lord!' at some prayer meetings related to the invocation of god in shamanistic practices.

3. Going to a mountain for pray is associated with shaman's practice of mountain prayer.

4. The expression of 'to receive a prayer' is related to the oracleseeking of Folk Religion.

5. The intentional tone variation of the minister at special prayer resembles the voice change of the shaman when she tries to get the oracle.

6. 'Wish-fulfilling thanks donation' or 'wish-fulfilling offering' resembles the give-and-take offerings of Folk Religion.

7. The rigorous rule of donation preparation is associated with that of sacrifice preparation of Folk Religion.

8. The invocation of blessing heard at donation prayers is related to that of Folk Religion.

9. The blessing-giving holy meeting at New Year's Eve is associated with Folk Religion's various forms of rituals at New Year. 
10. The impolite speech of some famous evangelists is associated with the speech style of shamans that they choose when granting oracle. $^{11}$

Such unique phenomena which are observed widely among protestant ministers and laymen can be explained from the assumption that the shamanistic machinery for wish-fulfillment has been accepted consciously or unconsciously. Korean Protestants are inclined to consider minister as a mediator who transmits their wishes like health, long life, success, promotion, admission, wealth and so on to God the Omnipotent and receives miraculous means of wish-fulfillment from God. Even some Ministers seem to order God to fulfill the wishes which are submitted Him. They seem to take over the job of shaman as master of the divinity. Therefore some Protestant ministers are blamed for being shamanized. But such a shamanistic ministry is not my concern.

\section{Toward a Proper Understanding of Shamanism and Shaman}

Korean shamanism is regarded as a branch of the shamanism in Siberia and Central Asia. The origin of the Koreans is not accurately investigated. But some archeological findings and the Korean language, which belongs to the Ural-Altai language family, indicate that forefathers of the Koreans originated in the northwestern area of Siberia, moved through the area around Baikal to the Korean Peninsula, expelled the natives and settled there.

M. Eliade presented his classical study on the shamanism in Siberia and Central Asia. He defined the shamanism as "archaic techniques of ecstasy." (ELIADE, 1970, p. 4) His definition started from the premise that the shamanism has its own intrinsic essence and structure before its historical development and transfiguration. The shamanism has appeared in various forms and shapes in different areas, but Elade has seen its essential and intrinsic distinction in ecstasy. It is beyond history and civilization. "There is no reason whatever for regarding it as the result of a particular historical moment, that is as produces by a certain form of civilization. Rather, we would consider it fundamental in the human condition, and hence known to the whole of archaic humanity." (ELIADE, 1970, p. 504) The shaman is

11 Bock-kyu Lee, "Unique Phenomena in Korean Protestantism and their Relationship with Folklore Religiosity," Korean Folklore 34 (2001/12), 165-175.(Korean edition) The summarized ten theses are the author's.(179f.) 
"the great master of ecstasy." It is true that magicians and medicine men experience ecstasy, but shaman's ecstasy has a particular specialty. "The shaman specializes in a trans during which his soul is believed to leave his body and ascend to the sky or descend to the underworld." (ELIADE, 1970 , p. 5) Ascent to the sky and descent to the underworld amounts to the essential sign of shaman's ecstasy. The shaman is chosen by the community, but in order to be recognized as shaman, he must acquire the capacity for ecstasy. Without exception a shaman candidate is afflicted with a certain "initiatory sickness" in which he or she falls into the first ecstatic experience. All the ecstatic experience of a shaman candidate involves "the traditional schema of an initiation ceremony: suffering, death, resurrection." (ELIADE, 1970, p. 33) In the first ecstasy the candidate has one or more of the following experiences: "dismemberment of the body, followed by a renewal of the internal organs and viscera; ascent to the sky and dialogue with the gods or spirits; descent to the underworld and conversations with spirits and the souls of dead shamans; various revelations, both religious and shamanic (secrets of profession)." (ELIADE, 1970, p. 34) After such ecstatic experiences the shaman becomes an entirely new person. In the initiatory sickness full of suffering and affliction the shaman apprehends the human conditions deeply. He hasn't overcome his initiatory sickness till he acquires the ability to cure others. As Eliade puts it, "like the sick man, the religious man is projected onto a vital plane that shows him the fundamental data of human existence, that is, solitude, danger, hostility of the surrounding world. But the primitive magician, the medicine man, or the shaman is not only a sick man; he is, above all, a sick man who has been cured, who has succeeded in curing himself." (ELIADE, 1970, p. 27) It is noteworthy, so I think, that the experience of the initiatory sickness provides the shaman with the ability to sympathize with others in suffering and sickness and to be in solidarity with the weak and the afflicted. Without the ability for sympathy and solidarity shaman's healing competency could lose its proper direction.

It is true that Eliade's understanding of shamanism as archaic techniques of ecstasy makes the fundamental structure of shamanism clear and distinct. But it is very problematic that his definition of shamanism has nothing to do with history, social structure and ideology. Therefore Eliade couldn't explain in which social structure and in which ideological frameworks shamanism came into being, and under which historical and cultural conditions shamanisms are differentiated from one another. Many 
scholars have made efforts to overcome such limits of Eliade's theory. First of all, it was S. M. Schirokogoroff, Russian specialist in Tungus shamanism, who paid attention to the tribe structure and the worldview which were, so he believed, the constituent elements of the Tungus shamanism. Furthermore, he analyzed that the Tungus shamanism had changed contents and forms of belief under the influence of Lamaism which had come to the area. ${ }^{12}$

In contrast with M. Eliade who thought that the ecstasy is "a primary phenomenon"13 I. M. Lewis regards possession as the very element of shamanism and approaches to the possession from a sociological perspective. He believes that ecstacy is a state of possession, that is, "seizure of man by divinity." Therefore, possession is primary and ecstasy follows it. "Transcendental experiences of this kind, typically conceived of as states of 'possession', have given the mystic a unique claim to direct experiential knowledge of the divine and, where this is acknowledged by others, the authority to act as a privileged channel of communication between man and the supernatural." (LEWIS, 2003, p. 15) He doesn't attempt to articulate a universal valid, therefore abstract definition of possession. Rather, he starts from the assumption that possession is "a culturally normative experience." (LEWIS, 2003, p. 57) Therefore, "if someone is, in his own cultural milieu, generally considered to be in a state of spirit possession, then he (or she) is possessed." (LEWIS, 2003, p. 40) In his sociological approach to shamanism he confirms two important facts. One is that shamanism is mainly accepted by women and settled as sub-culture in the patriarchal society in which men are dominant in the official sphere whereas women are driven into the unofficial sphere of life. ${ }^{14}$ The other fact is that, after his overcoming afflictions during his initiatory sickness, the shaman has "a special predilection for the weak and oppressed." (LEWIS, 2003, p. 64) It is notice worthy, so I think, that the shaman's sensitivity to suffering of the weak and oppressed is the basis for his or her sympathy with them and readiness for solidarity with them.

12 S. M. Shirokogoroff, Psychomental Complex of the Tungus (Berlin: Schletzer, 1999).(Original text: London, 1935)

13 It means that trans and possession can follow the ecstasy as accompanied phenomena. (ELIADE, 1970, p. 504)

14 I. M. Lewis, ibid., 80. In reliance upon I. M. Lewis Laurel Kendall shows clearly that in Korea the shamanistic household rites are performed mainly by women while the confucian rituals are practiced exclusively by men. For detailed explanation see Laurel Kendall, Shamans, Housewives, and Other Restless Spirits: Women in Korean Ritual Life (Honolulu: University of Hawaii Press, 1985), $27 \mathrm{f}$. 
Ake Hultkranz has examined thoroughly the studies and debates on shamanism after M. Eliade and attempted to reformulate shamanism as a complex of religious practices and belief which are integrated in a structure. On ground of such a careful definition of shamanism he has analyzed and summarized the role of shaman in the following four points:

1. The shaman makes contact with the spiritual world through the technique of ecstasy.

2. The shaman acts as mediator between human group and spirits for the sake of the welfare of them.

3. The shaman is inspired from her possession spirit as patron and becomes the master of spirits.

4. The shaman has ecstatic experiences. ${ }^{15}$

Korean scholars have studied the shamanism in three different directions. First, some scholars have explored Korean shamanism from the perspective of Eliade. Such a study is represented by Dong-sik Ryu. He believes that the shamanism is the archetype of Korean culture and underlies deep in it. The shamanism has been transfigured variously in encounter with foreign religions, but its archetype has remained without essential change. Various appearance forms of the shamanism in the history are nothing but derivation of the archetypical shamanism or its deterioration. ${ }^{16}$

Other scholars approach to Korean shamanism from a viepoint of psychology of religion. They depend mainly upon the analytic psychology of K. G. Jung. Pu-Yong Yi sees the archetype of collective unconsciousness in Korean shamanism, (YI, 1981, pp. 4-12) whereas Tae-gon Kim regards the shamanism as the archetype of Korean religiosity. ${ }^{17}$ The modern shamanism is therefore an appearance form of the archetypical psycho-structure which lies in the layer of Korean collective unconsciousness.

Lastly, a group of scholars assume a critical position against the above mentioned two viewpoints. These are not competent to explore historical,

15 Ake Hultkrantz, "An ecological and phenomenological Approach to Shamanism," Shamanism in Siberia, tr. by Gil-sung Choi into Korean (Seoul: Mineumsa, 1988). Original: Shamanism in Siberia, ed. by V. Dioszegi/M. Hoppal (Budapest: Akadémiai Kiadó, 1978). The original title of the article can be different from the title above.

16 Dong-sik Ryu, History and Structure of Korean Shamanism (Seoul: Yonsei University Press, 1975).(Korean edition)

17 Tae-gon Kim, A Study of Korean Shamanism (Seoul: Jipmoondang, 1981).(Korean edition) 
sociological and ideological contexts in which the shamanism originated, transfigured and developed itself. Seong-Nae Kim represents such a direction of shamanism study. She has employed the perspective of I. M. Lewis and A. Hultkranz and defined Korean shamanism as follows: "Korean shamanism is an ensemble of cultural knowledge about human being, nature and cosmos which is acquired by Korean common people in experiencing and exploring the worldly reality of life and a structure of symbolical imagination about transcendental powers." (KIM, 1998, p. 67) Such a definition is very helpful for explaining the particularity of Korean shamanism. Kim analyzes that unique characteristics of Korean shamanism have been formed in the cultural frameworks in which the Koreans have experienced and interpreted their everyday life. In so far as the cultural frameworks are endless changed, so the shamanism is always transfigured. Korean shamanism as religion is a model of reality used to conceptualize the relationship between person and society, between human beings and nature, and between human and supernatural beings. The model of reality changes as much as the reality. The modern shamanism has different contents from those of the traditional shamanism. The former is oriented to the prevailing individualism and materialism, while the latter was more community-oriented.

In order to end this brief and selective sketch of shamanism studies, I would like to emphasize the following three points. First, it is true that the distinctive mark of shamanism, regardless of its various appearance forms, lies in ecstasy and spirit possession. But it is very important to understand ecstasy and spirit possession as culture-bound, not as unhistorical. Second, I pay my attention to the point that the suffering and affliction which shamans have experienced in the initiation process make them sensitive to the suffering of the weak and oppressed. Third, in the patriarchal and class society the shamanism has formed a certain sub-culture and exercised its strong influence upon the underprivileged, especially upon women.

\section{Han and Hanpuri}

Han is the central concept which helps to understand the characteristics of Korean shamanism and shaman. In her case study on six mansin (great shaman) Young-sook Kim Harvey comes to the conclusion that they are worn out with han. ${ }^{18}$ After they suffered from sinbyong, possession sickness,

18 Young-sook Kim Harvey, Six Korean Women (Minnesota: West Publishing Co., 1979). 
with their internal organs and viscera worn out with han, they became shamans. According to Sun-hwa Seon, a feminist theologian, shaman's ecstatic experience during possession sickness as well as during gut can be explained from her unconscious choice to be liberated from her unfortunate life full of han. Korean shamans cannot be released from their han, because the prejudice toward shaman is still extremely severe in the Korean society. They live in the world, but they don't belong to the world. Such an existence sub contrario in the world forces them to seek for freedom and transcendence. (SEON, 1998 , p. 226) What is han on earth?

It is very difficult to explain what is han. Only who has suffered han can probably apprehend what is han and understand other people who suffer han also. The Koreans are familiar with han, because han is an underlying feeling of the Koran people. Eun Koh, a famous minjung poet, says: "We Koreans were born from the womb of han and brought up in the womb of han." (SUH, 1981, p. 54) Sometimes han expresses itself as resignation, adaption to reality, nihilism etc. Sometimes it explodes in the form of revenge, protest, revolt and so on. The former is named 'Junghan' and the latter is called 'wonhan'. In consideration of its various aspects han is conceived of as a complex of feelings. The Japanese and the Chinese don't know such complicated and nuanced connotations of han, although they use the same Chinese script for han (恨). In the Japanese context the word means simply grudge. In China the script has rather the meaning of repentance. From such comparison follows the consequence that han is culture-bound.

Yul-kyu Kim has employed the analytic psychology of K. G. Jung in order to investigate han as a dominant feeling among the Koreans. Kim regards han as shadow which comes from Korean collective unconsciousness. If han transfers positively, it is sublimated to the energy for a great achievement. But the negative transference of han leads to revenge. Such a transference mechanism is observed not only in personal dimension, but also in collective dimension. Collective han can express itself as the energy for revolution. The peasant war in 1896 is a good example for it. But collective han can evoke a vicious circle of revenge; the examples for it abide in history. ${ }^{19}$

What is made of han in shaman's sinbyong (initiatory sickness or possession sickness)? Scholars have interpreted Sinbyong variously. For psychiatrists sinbyong has been an interesting object of analysis. Kwang-il Kim,

19 Yul-kyu Kim, The Ore of 'Han' and the Stream of 'Won' (Seoul, Joowoo, 1081), $21 \mathrm{ff}$. 
a competent psychiatrist, defines sinbyong as "god sickness" and diagnoses it as "culture-bound depersonalization syndrome." (KIM, 1972, p. 223) According to him, shamans attain the ability to control trans and possession during sinbyong. The controlled trans and possession is categorized into the "transient regression of ego." In trans and possession occurs "the depersonalization of a person so that an ego faced with harsh reality enters another world - that of fantasy." (KIM, 1988, p. 146) Shamans have the techniques to induce the audience in rituals to trans and possession. What people seek in the naerimgut, namely shaman ritual for curing illness, is nothing but an infantile wishfulfillment. Gut involves "a temporary escape from the reality for a period of time with a certain return to reality" (KIM, 1988, p. 146); therefore the "transient regression of ego" sustains temporarily the healthiness of the ego. In a word, it has a hypnotic efficacy.

On the contrary, the folklorists consider sinbyong as a religious experience rather than a psychiatric symptom. They believe that the sinbyong results from the ban which is accumulated in the mind of a person who desperately seeks the eternal life in the world. For example, a sudden death of a closely associated person can invoke a disassociation of the ego and generate han in the deep layer of mind.

In her analysis of the initiation process of six mansin with various personal-historical backgrounds Young-sook Kim Harvey confirms that their experienced sinbyong was an expression of han. Even though their han is difficult to generalize, six mansin remembered their possession sickness as a path from the impass "between social expectations of them as women and their personal goals and interests as individuals." (KIM, 1979, p. 237) Such conflicts have remained for a long time unexpressed and their han has been accumulated as "a deep and abiding sense of having been morally injured as human beings.” (KIM, 1981, p. 247) For them there was no exit from such conflicts in the patriarchal society. Their han found at last an exit. It was the synbyong. In curing their own sinbyong they obtained the capacity to master their han and, furthermore, to help other persons to be released from their han. This coincides with the assumption of M. Eliade, I. M. Lewis, etc. that the shaman candidates gain the ability to cure others in overcoming afflictions in the initiation process.

Hanpuri is the central devices of shaman rituals. It has a variety of contents and patterns. Here I can present only a few limited examples. From a shamanistic perspective illness is aroused by the spirit of the dead who is 
not at all free from his or her han or by the spirit of the ancestor who is not properly treated. In order to cure the illness, shamans must identify the han of the dead and release him or her from the han; shamans must suggest the descendants the way to appease the spirit of their ancestor. - A house wife bears han in mind owing to the unsolvable conflict between mother in law and daughter in law or owing to husband's mistress. She suffers a lingering illness. In such a case the shaman practices the curing ritual to expose the han of the house wife and bring it to speech. The shaman opens a channel for communication among the concerned persons and tries to establish peace and reconciliation among them. - During the Korean war 1950-1953 many innocent people were killed in the war criminals or massacred. For a long time the killed and massacred have been forced by the authority to ignore. In the period of the enforced silence the han of the victims has been unceasingly brought into light through Jinoguigut. The shamans have stood in front of remembrance struggle.

But shaman's hanpuri is inclined to ignore the structure of evil from which han has originated. Shamanistic hanpuri is inclined to patch up peace and reconciliation among the people in conflicts without solving the structured conflicts in the reality. How can be the house wife released from her han, if the patriarchal structure of conflicts remains unchanged. Probably her husband paid the narimgut for curing her lingering illness. The comfort and catharsis which it brought her can be regarded as rewards for colluding in her oppression. (LEWIS, 2003, p. 78)

\section{Han and Dan}

Minjung theologians have defined han as the internal reality of Korean minjung who has suffered from political oppression, economical exploitation, socio-cultural marginalization, etc. Their interest in hanpuri practiced by shamans was so great to employ han and hanpuri as themes of theological reflection. But they have been critical to schaman's hanpuri with the argument that it is inclined to be the catharsis machinery without seeking for a radical change of the reality in which han generated. They believed that han is not only rooted in the personal-historical context of a person, but also comes into being owing to the structured evils in the reality. In the case that there is no exit from the suppression and suffering which the minjung endures in the structured evils, han cannot be but accumulated. It is the collective han of the minjung. Minjung theologians have put their special emphasis on the collective 
han. Therefore they have been distanced from the one-sided psychological approach to han. They have rather attempted to interpret ban from a political viewpoint. ${ }^{20}$ As David Kwang-sun Suh puts it, "the feeling of han is not just an individual feeling of repression. This is not just a sickness that can be cured by psychotherapy. This is a collective feeling of the oppressed. This sickness of han can be cured only when the total structure of the oppressed society and culture is changed." (SUH, 1981, p. 28)

Earlier, Younghak Hyun, one of the founders of Korean Minjung theology, attempted a theological look at the mask dance in Korea. He focused on the ability of the minjung for critical transcendence. He analyzed three aspects of critical transcendence. First, the experience of critical transcendence gives the minjung the energy to live in the fallen world with humor and without falling into despair. They are sure that the existing world is fallen and rotten, and that they are standing over against and beyond it. Because there seems to be no exit from it, they bear han in mind. But they must survive. They bear the hardship of the world with good humor and satire. It is the wisdom of the minjung. "Without such a wisdom they could not survive as human beings with dignity in a world where their dignity is not recognized." (HYUN, 1981, p. 48) Second, the experience provides the minjung with the courage to fight for change and freedom. Third, the experience of critical transcendence prevents them from self-righteousness. Therefore they can fight against the oppressors as well as against themselves. They can be free from self-righteousness so that they can change the existing world without seeking for revenge. Hyun argued that the experience of critical transcendence is the very basis for cutting off the vicious circle of bloody revenge.

In reliance on Chi-ha Kim's concept of the "dialectic unification of han and dan" Nam Dong Suh has attempted to reformulate what Hyun wanted to speak of with the concept "critical transcendence." Dan means literally cutting off. In the personal dimension dan is expressed as a resolute self denial, which leads to restraints from the comfort and easy life and so on. In the collective dimension dan means "cutting the chain of the circulation of

20 Jae Hoon Lee points out that the political interpretation of han is rather short-sighted. He distinguishes the original han from the secondary. The former resembles the shadow in the sense of K. G. Jung. On the basis of it the latter generates under influences of various factors. But the original han remains still unchanged in the layer of unconsciousness, if it is properly cured. Jae Hoon Lee, A Study of "Han" of the Korean People: A Depth Psychological Contribution to the Understanding of the Concept of "Han" in the Korean Minjung Theology, Dissertation (New York: Union Theological Seminary, December 1989), 49ff. 
ban." Dan is necessary for the transformation of the secular world and secular attachments. Han is fearful because it can explode as a destructive energy to create a vicious circle of evil. Therefore, the more han is accumulated, the more necessary dan is. As Chi-ha Kim puts it, "on the one hand, there is the fearful han which can kill, cause revenge, destroy and hate endlessly, and on the other, there is the repetition of dan to suppress the explosion which can break out of the vicious circle, so that han can be sublimated as higher spiritual power." (SUH, 1981, p. 61) Dan can happen because the bearer of han has the ability for self transcendence. In the experience of self transcendence he or she is no more tied to han, rather free from han. Who indescribably suffers han knotted in mind cannot fall into despair, but attain the tenacious life energy from the bottom. In Korea it is widely said that the minjung is like grassroots which survive, even if they are trodden and trodden. The phrase indicates how strong and tenacious the life energy of the minjung is. It is because of the life energy that they can see the heaven in the bottom of despair. I think that the minjung is privileged to see a light of hope in the darkness.

In his lay 'Chang Il-dam' Chi-ha Kim describes very movingly how the bottom of despair is turned up to the heaven. "The butcher Chang Il-dam is a wanted man. Having escaped from prison, he hides in a back street where prostitutes live. He happens to see one prostitute giving birth to a child. She is dying. Her body is rotten with venereal disease. She has tuberculosis; and she is also mentally ill. Yet, she is giving birth to a child. At the sight of it, he says, 'Ah, from a rotten body, new life is coming out! It is God who is coming out!' He learns the truth of the world. He kneels down and says, 'Oh, my mother, God is in your womb. God is the very bottom.' And he kisses her feet.” (SUH, 1981, p. 62)

Such a bold imagination is possible, so I think, if man has a firm belief in the tenacious life energy of the minjung. It is because of the ability to see the sky in the very bottom that they experience the critical transcendence. They stand over not only against themselves, but also against the fallen world. They fight against the existing world as well as against themselves. I see the possibility of transcendence in the experience of suffering. The experience of suffering provides the minjung with the sensitivity to suffering of others and strengthens their capacity to sympathize with others in suffering and to be in solidarity with them. The experience of suffering lets them unite and share hope with one another. They hope together a new world where the 
vicious circle of revenge is cut off, and where all the people live together in solidarity, justice and grand peace.

In order to articulate the priesthood of han, I return to the case of shaman once more. I think that shamans are talented for sympathy and solidarity with others in suffering because they have suffered their possession sickness. In overcoming the sickness they could cut off the tie of han and could be cured. I interpret it as shaman's self transcendence. It is because of their ability for self transcendence that shamans can practice hanpuri. The shamans who are cured of the possession sickness and released from han can help others to be free from han.

Nam Dong Suh has introduced Chi-ha Kim's concept of the "dialectic of han and dan" into a theological reflection on the role of the church and ministry. As Kim puts it, "The church ought to be the comforter to resolve the han of the minjung and to cut the vicious circle of violence, and to change it into a progressive movement. For this purpose, churches ought to accept limited violence, and ought to be a sanctuary for radicals and fighters who are progressing out of the dark." (SUH, 1981, p. 61)

In their political hermeneutics of han Korean Minjung theologians could pave the way to transform the energy condensed in han to the energy for justice, solidarity and peace. According to them, the priest of han should not seek for a false reconciliation and peace in the world where injustice and contradictions prevail. The priest of han ought to establish a reconciliation and peace based on justice. Only where the relationship among the people as well as among all the things in the world is straight and right, there can be enjoyed the fullness of life in justice. It is the grand peace. The priest of han has a vision of a world in unity and solidarity. It is a vision and hope of the life in peace based on justice. Korean Minjung theology will present such a vision and hope to this world where injustice, disorders, conflicts and war dominate.

\section{Conclusion}

From the interfaith dialogue between Christianity and shamanism I would like to draw a few consequences. First of all, I suggest that Christian minister should learn something from the attitude of shamans towards the weak and oppressed. They have "a special predilection for the weak and oppressed" (I. M. Lewis) and are ready to be in solidarity with others in suffering. Of course, Christian minister need not to suffer the initiation sickness like shamans, but 
they must be trained to attain a spiritual competency to sympathize and to be in solidarity with the little people in suffering.

Second, I think that the church should be earnest to the priesthood of han. It is not just the duty of the minister. The priesthood of han should be reinterpreted from the perspective of the priesthood of all believers. Only when all believers practice the priesthood of han, then the church can be engaged in the movement to change the existing world radically and to open the world in justice, solidarity and grand peace.

\section{Bibliography}

Cha, Nam-hee, "Political Change and Shamanism in the ancient Korean society," Korean Politics 39/2 (2005/6).

Eliade, Mircea, Shamanism: Archaic Techniques of Ecstasy, tr. from the French by Williard R. Trask (New York: Bollingen Foundation, 1970).

Hultkrantz, Ake, "An ecological and phenomenological Approach to Shamanism," Shamanism in Siberia, tr. by Gil-sung Choi into Korean (Seoul: Mineumsa, 1988). Original: Shamanism in Siberia, ed. by V. Dioszegi/M. Hoppal (Budapest : Akadémiai Kiadó, 1978).

Hyun, Younghak, "A Theological Look at the Mask Dance in Korea," Minjung Theology: People as The Subject of History, ed. by Yong Bock Kim (Singapore: A CTC-CCA Publication, 1981).

Kendall, Laurel, Shamans, Housewives, and Other Restless Spirits: Women in Korean Ritual Life (Honolulu: University of Hawaii Press, 1985).

Kim, In-hoe, "Korean Shamanism: A Bibliographical Introduction," Shamanism: The Spirit World of Korea, ed by Chai-shin Yu and R. Guisso (Berkeley, Califonia: Asian Humanities Press, 1988).

Kim, Kwang-il, "Sin-byong: A Culture-Bound Depersonalization Syndrome in Korea," Neuropsychiatry 11 (1972).

Kim, Kwang-il, "Kut and the Treatment of Mental Disorders," Shamanism: The Spirit World of Korea, ed. by Chai-shin Yu and R. Guisso (Berkeley, Califonia: Asian Humanities Press, 1988).

Kim, Seung-Hye/Seong-Nae Kim, Christianity and Shamanism (Seoul: Paul's Daughters, 1998), 67.(Korean edition)

Kim, Tae-gon, A Study of Korean Shamanism (Seoul: Jipmoondang, 1981).(Korean edition)

Kim, Yul-kyu, The Ore of 'Han' and the Stream of 'Won' (Seoul, Joowoo, 1981).

Kim Harvey, Young-sook, Six Korean Women (Minnesota: West Publishing Co., 1979).

Lee, Bock-kyu, "Unique Phenomena in Korean Protestantism and their Relationship with Folklore Religiosity,” Korean Folklore 34 (2001/12).

Lee, Yong-bum, "A Study on the Negative View on the Shamanism in the Korean modern Society," Studies on Korean Shamanism 9 (2005/2). 
Lim, Jae-hae, "The political Function of Gut Culture and the Political Status of Shaman," Comparative Folklore 26 (2004/2).

Lee, Jae Hoon, A Study of "Han" of the Korean People: A Depth Psychological Contribution to the Understanding of the Concept of "Han" in the Korean Minjung Theology, Dissertation (New York: Union Theological Seminary, December 1989)

Lewis, I. M., Ecstatic Religion : A Study of Shamanism and Spirit Possession, $3^{\text {rd }}$ ed. (London/New York: Routledge, 2003).

Seon, Sun-hwa, "How to see the Shamanism from a Christian's Perspective?", Christianity and Shamanism, ed. by Seung-Hye Kim/Seong-Nae Kim (Seoul: Paul's Daughters, 1998).

Shirokogoroff, S. M., Psychomental Complex of the Tungus (Berlin: Schletzer, 1999).(Original text: London, 1935)

Ryu, Dong-sik, History and Structure of Korean Shamanism (Seoul: Yonsei University Press, 1975). (Korean edition)

Ryu, Dong-sik, Korean Religions and the Christianity (Seoul: The Christian Literature Society of Korea, 1965).

Suh, David Kwang-sun, "Minjung and Theology in Korea: A Biographical Sketch of an Asian Theological Consultation," Minjung Theology: People as The Subject of History, ed. by Yong Bock Kim (Singapore: A CTC-CCA Publication, 1981).

Suh, Nam Dong, "Towards a Theology of Han," Minjung Theology: People as The Subject of History, ed. by Yong Bock Kim (Singapore: A CTC-CCA Publication, 1981).

Yi, Pu-Yong, "Illness and Healing in Three Kingdom Period," Korea Journal 21/12 (December 1981). 